\title{
BRAZILIAN SOCIAL AND ECONOMIC DEVELOPMENT DEPENDS ON SCIENCE
}

Atson Carlos de Souza Fernandes

$\mathrm{PhD}$ in Morphology. Professor at the State University of Bahia and at BAHIANA - School of Medicine and Public Health. Assistant dean of Research and Innovation at BAHIANA. Salvador, Bahia, Brazil. atsonfernandes@yahoo.com.br

Brazil is currently recognizing the importance of science as a societal transforming agent. In the XXI century, ST\&I (Science, Technology and Innovation) has become the greatest symbol of development, wealth and power of a nation ${ }^{1,2}$.

However, in spite of all the research investments made by Brazil, which has ranked the country in the 13th place in international scientific production ${ }^{3,4}$, the knowledge generated has exerted little impact on our economic growth, sustainability and social inclusion. That, at least in part, explains why we currently rank 69th in global innovation ${ }^{5}$.

In summary, Brazil's worldwide contribution to scientific knowledge has not positively impacted the R\&D chain, responsible for innovation indicators including the development of new products, processes, inputs, markets and forms of organizations.

This scenario is probably a reflection of the research model we practice, where basic research has been our principal focus. As a consequence, we observe a scarcity of investments in Brazilian research when compared to the reality of what is practiced in developed countries, where there is a predominance of research funding made by industry in relation to government incentive. While the business sector in countries such as the Unites States of America, Germany, China, South Korea and Japan is responsible for up to $70 \%$ of the total R\&D spending, Brazil's private funding of research reaches a maximum of $45 \%$.

Another reality that impacts our scientific development is the reduced availability of qualified professionals. While the number of scientists per million inhabitants in countries with higher indicators of wealth and social development such as South Korea, Finland, Sweden and Denmark is $6,457,7,188$, 6,473 and 7,265 , respectively, in Brazil we currently have less than 700 scientists per million inhabitants?

These numbers point towards the necessity to invest in the qualification and professional training of Brazilian personnel through undergraduate and graduate courses. According to the goals of the Brazilian National Education Plan ${ }^{8}$ by the year 2020 we must produce 25 thousand $\mathrm{PhD}$ per year. However, we still have a limited number 
of graduate courses and a serious problem of asymmetry in the distribution of these programs, which are deficient in the northern and northeastern regions of the country.

It is therefore evidenced that the role of the University goes beyond the promotion and production of knowledge. In the current "ecosystem" of economic and social development in which the productive sector and Government participate, the University plays a fundamental role in transforming knowledge into solutions that brings benefits to society. According to Garnica et al (2009), "the use of knowledge generated in Brazilian universities represents a rich source of information and training for the development of new technologies, resulting in the transfer of technology between universities and the productive sector. An alternative and complementary way to reach a higher technological level for Brazilian companies".

In this scenario, the Brazilian Federal Law $N^{\circ} 13.243^{\circ}$, known as the Legal framework for Science, Technology and Innovation was passed in January $11 \mathrm{th}, 2016$. This legal framework "provides stimuli to scientific development, research, scientific and technological capacity-building and innovation". This law seeks to encourage strategic partnerships and the development of cooperation projects between the academy and companies, which are a rich source of information and training for the development of new technologies that when transferred to the productive sector, will promote the development of products, processes and innovative services ${ }^{10}$.

However, in addition to stimulating applied research with potential for technological development and innovation, and producing a qualified critical mass of professionals, it is also the University's role to develop the entrepreneurial spirit during the academic-professional training. In this new scenario of collaboration between academy and industries, managers, researches and students need to be prepared to work together to promote the next generation of products, jobs, wealth, income, sustainability and quality of life for society ${ }^{6}$.

In this new culture of entrepreneurship for the sciences, the system runs as a triple helix model composed by the State as a policy generator and coordinator of macro issues related to the public interest, the Scientific and Technological Institutions as human resource trainers and enablers of the human critical mass necessary for the development of applied research, and the productive sector where the innovation takes place.

\section{REFERENCES}

1. Brasil. Ministério da Ciência e Tecnologia. PACTI - Plano de Ação 2007-2010: Ciência, Tecnologia e Inovação para - Desenvolvimento Nacional, elaborado pelo Ministério da Ciência e Tecnologia (MCT). Brasília. DF. Portuguese.

2. Brasil. Ministério da Ciência, Tecnologia e Inovação. ENCTI - Estratégia Nacional de Ciência, Tecnologia e Inovação 2012-2015. Brasília. DF. 2012 . Portuguese.

3. Reuters T. Journals In The 2015 Release of JCR. Journal Citation Reports. 2015;1-400.

4. Brasil. Ministério de Ciência e Tecnologia. Portal Brasil. Brasil está entre 25 primeiros lugares no ranking de artigos científicos. [Internet]. 2015 [Acesso em 27 nov. 2016 ]. Availble from: http://www.brasil.gov.br/cienciaetecnologia/2015/06/brasil-esta-entre-25-primeiroslugaresno-ranking-de-artigos-cientificos. Portuguese.

5. Cornell University, INSEAD, and WIPO: The Global Innovation Index 2016: Winning with Global Innovation, Ithaca, Fontainebleau, and Geneva. 2016.

6. Fernandes ACS. Pesquisa e inovação: o estado da arte. Revista Bahiana de Odontologia. 2016;7(4):240-242. doi: 10.17267/2238-2720revbahianaodonto.v7i4.1 188. Portuguese.

7. Zanotto SR, Haeffner C, Guimarães JA. Unbalanced international collaboration affects adversely the usefulness of countries' scientific output as well as their technological and social impact Scientometrics. 2016;109(3):1789-1814.

8. Brasil. Plano Nacional de Educação. Lei $n^{\circ} 13.005$, de 25 de junho de 2014. Brasília. DF. 2014. Portuguese.

9. Brasil. Lei 13.243/2016, de 11 de janeiro de 2016 . Brasília. DF. 2016 . Portuguese.

10. Garnica LA, Torkomian ALV. Gestão de tecnologia em universidades: uma análise do patenteamento e dos fatores de dificuldade e de apoio à transferência de tecnologia no Estado de São Paulo. Gestão \& Produção. 2009; 16(4):624639. Portuguese. 